\title{
Gene-for-Gene Defense of Wheat Against the Hessian Fly Lacks a Classical Oxidative Burst
}

\author{
Marcelo P. Giovanini, ${ }^{1}$ David P. Puthoff, ${ }^{2,3}$ Jill A. Nemacheck, ${ }^{2,3}$ Omprakash Mittapalli, ${ }^{3}$ \\ Kurt D. Saltzmann, ${ }^{2,3}$ Herbert W. Ohm, ${ }^{1}$ Richard H. Shukle, ${ }^{2,3}$ and Christie E. Williams ${ }^{2,3}$ \\ ${ }^{1}$ Department of Agronomy, Purdue University, 915 W. State St., West Lafayette, IN 47907, U.S.A.; ${ }^{2}$ United States \\ Department of Agriculture-Agricultural Research Service (USDA-ARS) Crop Production and Pest Control Research Unit, \\ West Lafayette, IN 47907, U.S.A.; ${ }^{3}$ Department of Entomology, Purdue University, 901 W. State St., West Lafayette, \\ IN 47907, U.S.A.
}

Submitted 18 December 2005. Accepted 15 April 2006.

Genetic similarities between plant interactions with microbial pathogens and wheat interactions with Hessian fly larvae prompted us to investigate defense and counterdefense mechanisms. Plant oxidative burst, a rapid increase in the levels of active oxygen species (AOS) within the initial $24 \mathrm{~h}$ of an interaction with pathogens, commonly is associated with defenses that are triggered by gene-for-gene recognition events similar to those involving wheat and Hessian fly larvae. RNAs encoded by Hessian fly superoxide dismutase $(S O D)$ and catalase (CAT) genes, involved in detoxification of AOS, increased in first-instar larvae during both compatible and incompatible interactions. However, mRNA levels of a wheat NADPH oxidase $(\mathrm{NOX})$ gene that generates superoxide $\left(\mathrm{O}_{2}^{-}\right)$did not increase. In addition, inhibiting wheat NOX enzyme with diphenyleneiodonium did not result in increased survival of avirulent larvae. However, nitro blue tetrazolium staining indicated that basal levels of $\mathrm{O}_{2}^{-}$are present in both uninfested and infested wheat tissue. mRNA encoded by wheat genes involved in detoxification of the cellular environment, $S O D, C A T$, and glutathione- $S$-transferase did not increase in abundance. Histochemical staining with 3,3-diaminobenzidine revealed no increases in wheat hydrogen peroxide $\left(\mathrm{H}_{2} \mathrm{O}_{2}\right)$ during infestation that were correlated with the changes in larval $S O D$ and $C A T$ mRNA. However, treatment with $2^{\prime}, 7^{\prime}$-dichlorofluorescin demonstrated the presence of basal levels of $\mathrm{H}_{2} \mathrm{O}_{2}$ in the elongation zone of both infested and uninfested plants. The accumulation of a wheat flavanone 3-hydroxylase mRNA did show some parallels with larval gene mRNA profiles. These results suggested that larvae encounter stresses imposed by mechanisms other than an oxidative burst in wheat seedlings.

Corresponding author: Christie Williams; E-mail: cwilliams@purdue.edu

Current address of D. P. Puthoff: USDA-ARS, MPPL BARC-West, 10300 Baltimore Ave. Beltsville, MD 20705, U.S.A.

Use of commercial or proprietary products to the exclusion of others does not constitute endorsement by the USDA.

Nucleotide sequence data is available in the GenBank database under accession numbers DV752666, DV752667, AF017427, AY561153, and DQ208192.

This article is in the public domain and not copyrightable. It may be freely reprinted with customary crediting of the source. The American Phytopathological Society, 2006.
Additional keywords: flavonoid, oxidative stress, quantitative real-time polymerase chain reaction, SYBR Green.

Many plant species initiate an oxidative burst as the first step in a complex cascade of resistance events leading to pathogen death (Doke 1985; Kepler et al. 1989). The oxidative burst begins within a matter of minutes to a few hours after initial attack. The rapid response is possible because preexisting NADPH oxidase (NOX) enzyme complexes, capable of generating active oxygen species (AOS), reside in the plasma membrane (Lamb and Dixon 1997) or are exocellular (Bolwell and Wojtaszek 1997). Although the oxidative burst is initiated too quickly to depend on de novo synthesis of enzymes (Doke 1983), increases in RNAs encoding oxidant-generating enzymes probably maintain the response (Lamb and Dixon 1997). The one-electron reduction of molecular oxygen to form the superoxide anion $\left(\mathrm{O}_{2}^{-}\right)$is catalyzed by NADPH oxidase $\left(\mathrm{O}_{2}+\right.$ $\mathrm{NADPH} \rightarrow \mathrm{O}_{2}^{-}+\mathrm{NADP}^{+}+\mathrm{H}^{+}$) (Lamb and Dixon 1997). Superoxide anions then undergo either spontaneous dismutation (Sutherland 1991) or are catalyzed by superoxide dismutase (SOD) to form hydrogen peroxide $\left(\mathrm{H}_{2} \mathrm{O}_{2}\right)$ in the apoplasts, cytosol, chloroplasts, or mitochondria (Scandalios 1993).

The accumulation of AOS is harmful to the host plant cells; consequently, antioxidant enzymes such as catalases (CAT) and glutathione $S$-transferases (GST) commonly are involved in scavenging AOS from the cellular environment (Levine et al. 1994). The AOS (superoxide, hydroxyl radicals, and hydrogen peroxide) act directly to kill pathogen cells (Dixon et al. 1994), as well as cross-linking plant cell wall proteins for reinforcement (Cosgrove et al. 2000), signaling up-regulation of defense genes (Levine et al. 1994), and triggering plant cell death through a hypersensitive response (HR) that restricts pathogen growth (Dixon et al. 1994).

Other mechanisms are capable of generating AOS. For example, the mitochondrial Krebs cycle generates AOS as natural byproducts of respiration (Bolwell and Wojtaszek 1997). In addition, some flavonoids can act as pro-oxidants to generate AOS (Hodnick et al. 1989). Certain flavonoids become activated only after ingestion, so that AOS are produced inside the insect rather than in plant tissues (Ahmad and Pardini 1990).

Although herbivorous insects utilize mechanisms for nutrient acquisition that differ greatly from those of microbial pathogens, certain feeding strategies result in similar defense responses. Evidence for an insect-induced oxidative burst has been reported for sorghum plants infested with the greenbug aphid (Schizaphis 
graminum (Rondani)). This interaction results in differential expression of sorghum GST and CAT, suggesting AOS accumulation and detoxification (Zhu-Salzman et al. 2004). AOSassociated HR surrounds pathogens with dead tissue that serves as a barrier to limit lesion expansion. HR also has been effective in limiting nutrient acquisition by sessile insects like bark beetles (Berryman and Ferrell 1988) and gall midge larvae (Fernandes and Negreiros 2001). The Hessian fly, Mayetiola destructor (Say), is a member of the gall midge family, although it does not induce true gall formation and becomes sessile after the first larval molt. Interactions of Hessian fly larvae with wheat (Tritium aestivum L. em Thell.) can result in extensive areas of cell collapse, resembling an HR, within 2 days of egg hatch (Grover 1995).

Unlike the larvae of many phytophagous insects, Hessian fly larvae do not destructively consume wheat tissue by chewing, or bore holes in stems. Instead, they make only small wounds in a few cells and are believed to inject salivary compounds that initiate interactions with the plant (Grover 1995; Hatchett et al. 1990). This type of attack is similar to interactions initiated by fungi, nematodes, and many other pathogens that, like Hessian fly larvae, trigger a gene-for-gene recognition by a resistant host (Hatchett and Gallun 1970) and cause physiological rather than extensive physical damage to a susceptible host. Components of the larval saliva (Liu et al. 2004) are hypothesized to subvert the development of the susceptible host, leading to alterations in mRNA levels (Puthoff et al. 2005; Sardesai et al. 2005; Subramanyam et al. 2006) and plant cell fate (Harris et al. 2006) that are necessary for insect development.

During compatible interactions with developing seedlings, Hessian fly larvae establish feeding sites among the leaf sheaths near the crown at the base of the plant. Larval feeding on susceptible plants induces a generalized increase in leaf sheath cell permeability within 5 days of the initiation of the interaction (Shukle et al. 1992). This permeability allows nutrients to move to the surface of the leaf sheath for larval consumption and is associated with the formation of gall-like nutritive tissue (Harris et al. 2003, 2006). Feeding by virulent larvae not only stunts plant growth but also causes seedlings to accumulate more chloroplasts (Cartwright et al. 1959; Robinson et al. 1960). Second-instar larvae continue to feed but are incapable of injecting secretions into the plant (Hatchett et al. 1990). The irreversible changes in wheat tissues create a satisfactory environment to allow larval growth by delivering nutrients and protecting the larvae among the stunted leaf sheaths.

During incompatible interactions, larval salivary components trigger recognition, and the resulting activation of wheat genes involved in defense (Williams et al. 2002) can be detected within 6 to $12 \mathrm{~h}$ of egg hatch (Sardesai et al. 2005; Subramanyam et al. 2006). However, the first-instar larvae do not die immediately. Rather, they continue to probe and move down the plant for 3 to 4 days (Gallun 1977; Grover 1995) and are unable to alter plant physiology and development to establish permanent feeding sites (Grover 1995). Avirulent larvae die later than the 2-day time point in which Grover (1995) observed plant cell necrosis. The cause of larval death, however, may be due to any combination of factors, not limited to a localized oxidative burst-associated HR. Other factors may include ingestion of lectins that block absorption of nutrients or feeding deterrents that lead to starvation. This incompatible interaction appears to have little impact on the plant because infested, resistant wheat plants exhibit relatively normal growth (Gallun et al. 1961).

When plants are attacked by a population of both virulent and avirulent larvae, as occurs in many field infestations, both larval genotypes develop to maturity (Grover et al. 1989) even if avirulent larvae hatch and begin probing before virulent larvae (C. E. Williams and J. A. Nemacheck, unpublished data). The form of resistance induced by avirulent larvae does not kill virulent larvae that are only a few millimeters away; therefore, plant resistance mechanisms appear to be very localized, involving modes of action such as the production of feeding deterrents and defense molecules primarily in a few cells at the point of contact. However, induced susceptibility in the plant appears to be somewhat systemic because avirulent larvae of mixed infestations survive due to their proximity to the nutritive tissue-inducing virulent larvae.

Many insects are able to overcome the effects of host-plant AOS via an antioxidant defense mechanism consisting of the enzymes SOD, CAT, glutathione reductase, and thioredoxin reductase (Missirlis et al. 2001). In a mechanism parallel to the AOS-scavenging pathway of plants, SOD of virulent cabbage looper larvae (Trichoplusia ni Hübner) catalyzes the dismutation of $\mathrm{O}_{2}^{-}$to $\mathrm{H}_{2} \mathrm{O}_{2}$, which then is converted to $\mathrm{H}_{2} \mathrm{O}$ and $\mathrm{O}_{2}$ by the action of larval CAT (Ahmad and Pardini 1990). In that study, a twofold increase in SOD enzyme activity is the primary response of the insect to dietary AOS.

Plant production of AOS, associated with an HR that limits pathogen growth, is a commonly observed defense mechanism triggered by gene-for-gene interactions. Because well-defined mechanisms of resistance have not been identified in the genefor-gene interactions that trigger the resistance of wheat against the Hessian fly, we initiated a search for evidence of a classical oxidative burst. Hessian fly larval $S O D$ and $C A T$ mRNAs became more abundant during the initial days of the interaction, suggestive of plant-imposed stress. We then assayed infested wheat plants for evidence of oxidative burst-associated AOS and for increased levels of mRNAs that encode enzymes involved in generating or in scavenging AOS. However, no evidence was found of oxidative stress occurring within the plant tissues. In contrast, flavanone 3-hydroxylase (F3H) RNAs increased rapidly in incompatible but slowly during compatible interactions. Although a classical oxidative burst was eliminated as a mechanism responsible for changes in larval $S O D$ and CAT mRNA levels, the causal mechanisms of plant defense are yet to be identified.

\section{RESULTS}

Accumulation of Hessian fly $S O D$ and $C A T$ mRNA.

Gene-specific primers (Table 1) for quantitative real-time polymerase chain reaction (q-RT-PCR) were designed for Hessian fly $S O D$ (mdesSOD-1) and CAT genes (mdesCAT-1). mRNA levels were quantified during development of Biotype L Hessian fly larvae on wheat plants containing the $H 9$ resistance gene Iris- $H 9$ (incompatible interaction) or on the susceptible nearly isogenic wheat line Newton (compatible interaction). A gradual increase was seen for both $S O D$ and $C A T$ mRNA levels from larvae involved in compatible interactions (Fig. 1A and B, dashed lines; arbitrary expression values [AEV] shown in log scale), suggesting a growing response to environmental stress over time. However, throughout the experiment, larval SOD mRNA remained significantly lower in incompatible than in compatible interactions. For example, 4 days after hatch, larval SOD mRNA was 4.61-fold $(P=1.6 \mathrm{E}-09)$ more abundant in compatible than in incompatible interactions; the fold change was calculated from non-log scale AEV. In addition, levels of larval CAT mRNA increased earlier in incompatible than in compatible interactions. One day after hatch, larval $C A T$ mRNA was 2.08 -fold $(P=7.1 \mathrm{E}-07)$ more abundant in incompatible interactions. These data suggest that larvae involved in both compatible and incompatible interactions were responding to some type of stress. 


\section{Accumulation of mRNA from a wheat gene associated with production of AOS.}

Wheat $N O X$ mRNA levels were quantified by q-RT-PCR to determine whether the accumulation of wheat NOX mRNA was responsive to feeding by first-instar Hessian fly larvae and, thus, may be a source of oxidative stress. NOX was chosen because it encodes an enzyme believed to sustain $\mathrm{O}_{2}^{-}$production after the initial oxidative burst that utilizes preexisting enzymes (Doke 1983). We cloned a partial cDNA sequence of the wheat NOX gene that included 794 bp of the predicted 2,782-bp mRNA and was $89 \%$ identical and $95 \%$ similar to the rice NOX gene $R b o h A$. The wheat NOX-predicted amino acid sequence was $92 \%$ identical to the RbohA-deduced protein sequence, which is similar to the mammalian $\mathrm{g} p 91^{\text {phox }}$ respiratory burst NOX gene (Groom et al. 1996). Therefore, we concluded that we had cloned a sequence from a wheat NOX gene.

The observed increases in larval SOD and CAT mRNA were independent of wheat $N O X$ mRNA abundance during the first $24 \mathrm{~h}$ of the interaction. NOX message levels remained low in uninfested controls, compatible interactions (Iris- $H 9$ wheat with $v H 9$ larvae), and incompatible interactions (Iris- $H 9$ wheat with Biotype L larvae) (Fig. 2A). Likewise, no change was seen in samples collected 2, 3, 4, or 8 days after egg hatch (all $P$ values $>0.05$; data not shown). The first through fifth leaves were measured 17 days after egg hatch, confirming that the plants had reacted correctly to the larvae (compatible produced stunted plants, incompatible and controls produced plants of normal height) (Fig. 2B). The low levels of NOX mRNA in all samples suggested that changes in NOX RNAs were not a response of wheat to Hessian fly larval feeding.

\section{Inhibition of NADPH oxidase complexes.}

Although changes in wheat NOX mRNA levels were not detected in response to Hessian fly larvae, levels of the NADPH complex present in the plasma membrane prior to infestation may be sufficient to activate an oxidative burst. Diphenyleneiodium (DPI) treatment of nearly isogenic wheat lines '97211' and 'Len' was performed to assess the involvement of superoxide-producing NOX complexes in defense against Biotype L Hessian fly larvae. Wheat seedlings growing under hydroponic conditions were treated with DPI (Auh and Murphy 1995; O'Donnell et al. 1993), which binds to the flavoprotein component of the NOX complex (Cross and Jones 1986). If NOX complexes were essential to the resistance response, inhibition would decrease plant production of $\mathrm{O}_{2}^{-}$, resulting in increased survival of larvae on resistant 97211 plants.
Larval counts 5 days after egg hatch indicated that DPI inhibition of NOX complexes under hydroponic conditions did not result in increased larval survival. In the presence of DPI, resistant plants still were able to mount defenses leading to $100 \%$ larval death, with the exception of one plant harboring two larvae that were believed to be genetically virulent genotypes contaminating the Biotype L stock (in all, 25 larvae were present, only 2 of which were virulent) (Fig. 2C, resistant white bar). The remaining resistant plants (97211) treated with DPI were able to mount a normal defense response against the avirulent larvae, as indicated by the presence of dead, red larvae. Low-level contamination was confirmed

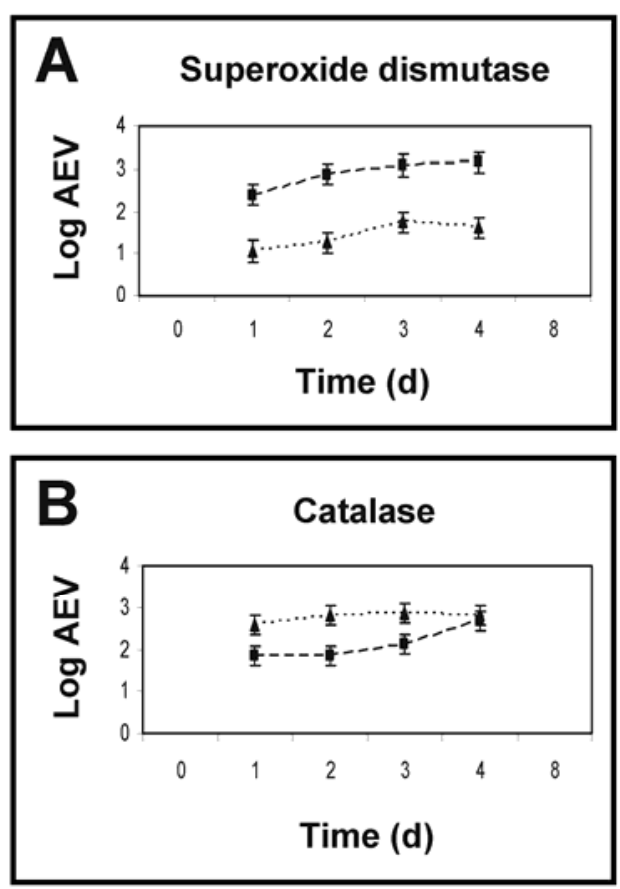

Fig. 1. mRNA levels for two Hessian fly genes involved in active oxygen species-scavenging. mRNA levels were quantified by quantitative realtime polymerase chain reaction (q-RT-PCR) 1 through 4 days after egg hatch in Biotype $\mathrm{L}$ larvae feeding on Iris- $\mathrm{H} 9$ wheat plants (incompatible interaction, dotted line) and Newton wheat (compatible interaction, dashed line). Log of the arbitrary expression values (Log AEV) is shown. Error bars represent standard error from the analysis of variance test. Each graph represents three independent experiments, each subjected twice to q-RTPCR. A, Hessian fly $S O D$ and B, Hessian fly CAT mRNA levels.

Table 1. Wheat and Hessian fly gene-specific primers used in quantitative real-time polymerase chain reaction

\begin{tabular}{|c|c|c|c|}
\hline Gene & Accession & Origin & Primer sequence $^{a}$ \\
\hline \multirow[t]{2}{*}{$C A T$} & X94352 & Wheat & (F) 5' TCGGACACCGAGGACCTATC 3' \\
\hline & $\ldots$ & $\ldots$ & (R) 5' CCGTGCATGAACAACACGTT 3' \\
\hline \multirow[t]{2}{*}{$F 3 H$} & DQ208192 & Wheat & (F) 5' GTCGTGGATGAGGCAAGCTT 3' \\
\hline & $\ldots$ & $\ldots$ & (R) 5' ACTACAAGAAGTTCTGGAGCAGGAA 3' \\
\hline \multirow[t]{2}{*}{$G S T$} & AF109714 & Wheat & (F) 5' AGTCACCATGCGTGGAAGAAG 3' \\
\hline & $\ldots$ & $\ldots$ & (R) 5' AATCTCACTGGTGGTGAATCGAT 3' \\
\hline \multirow[t]{2}{*}{$N O X$} & AY561153 & Wheat & (F) 5' ATGTTCGGCAACTTGGTGACT 3' \\
\hline & $\ldots$ & $\ldots$ & (R) 5' CGTCTGCTCTAAGAAGACCACTTTT 3' \\
\hline \multirow[t]{2}{*}{$S O D$} & CB307850 & Wheat & (F) 5' CCGAGGTCTGGAACCATCAC 3' \\
\hline & $\ldots$ & $\ldots$ & (R) 5' AGCCGAAATCCTTCTCGATCT 3' \\
\hline \multirow[t]{2}{*}{$U B Q$} & X56803 & Wheat & (F) 5' GGTGTCTCCGGTATCCTCCAA 3' \\
\hline & $\ldots$ & $\ldots$ & (R) 5' TGCTCCACACCAGCAGAAGT 3' \\
\hline \multirow[t]{2}{*}{$A C T$} & AF017427 & Hessian fly & (F) 5' ATGTGTGACGACGAAGTTGCT 3' \\
\hline & $\ldots$ & $\ldots$ & (R) 5' GGCAACATACATGGCTGGTG 3' \\
\hline \multirow[t]{2}{*}{$C A T$} & DV752667 & Hessian fly & (F) 5' ATGTTTTGGGATTTTATTTCATTG 3' \\
\hline & $\ldots$ & $\ldots$ & (R) 5' GGAGATGGTTCGATTCCTGGTACCA 3' \\
\hline \multirow[t]{2}{*}{$S O D$} & DV752666 & Hessian fly & (F) 5' ATGGTTAAAGCAGTTTGTGTTATTG 3' \\
\hline & $\ldots$ & $\ldots$ & (R) 5' ATACCAATGAACACCGCAACCAAT 3' \\
\hline
\end{tabular}

${ }^{\mathrm{a}} \mathrm{F}=$ forward and $\mathrm{R}=$ reverse. 
when four Biotype L larvae survived on three resistant 97211 plants grown in vermiculite without DPI (on 12 plants, a total of 328 larvae were present, only 4 of which were virulent) (Fig. 2C, resistant black bar). Both groups of susceptible Len plants, those treated with DPI and untreated plants, exhibited normal compatible interactions (Fig. 2C, white and striped bars). However, an average of 2.5 larvae on Len plants treated with DPI did die (Fig. 2C, susceptible white bar), suggesting a small
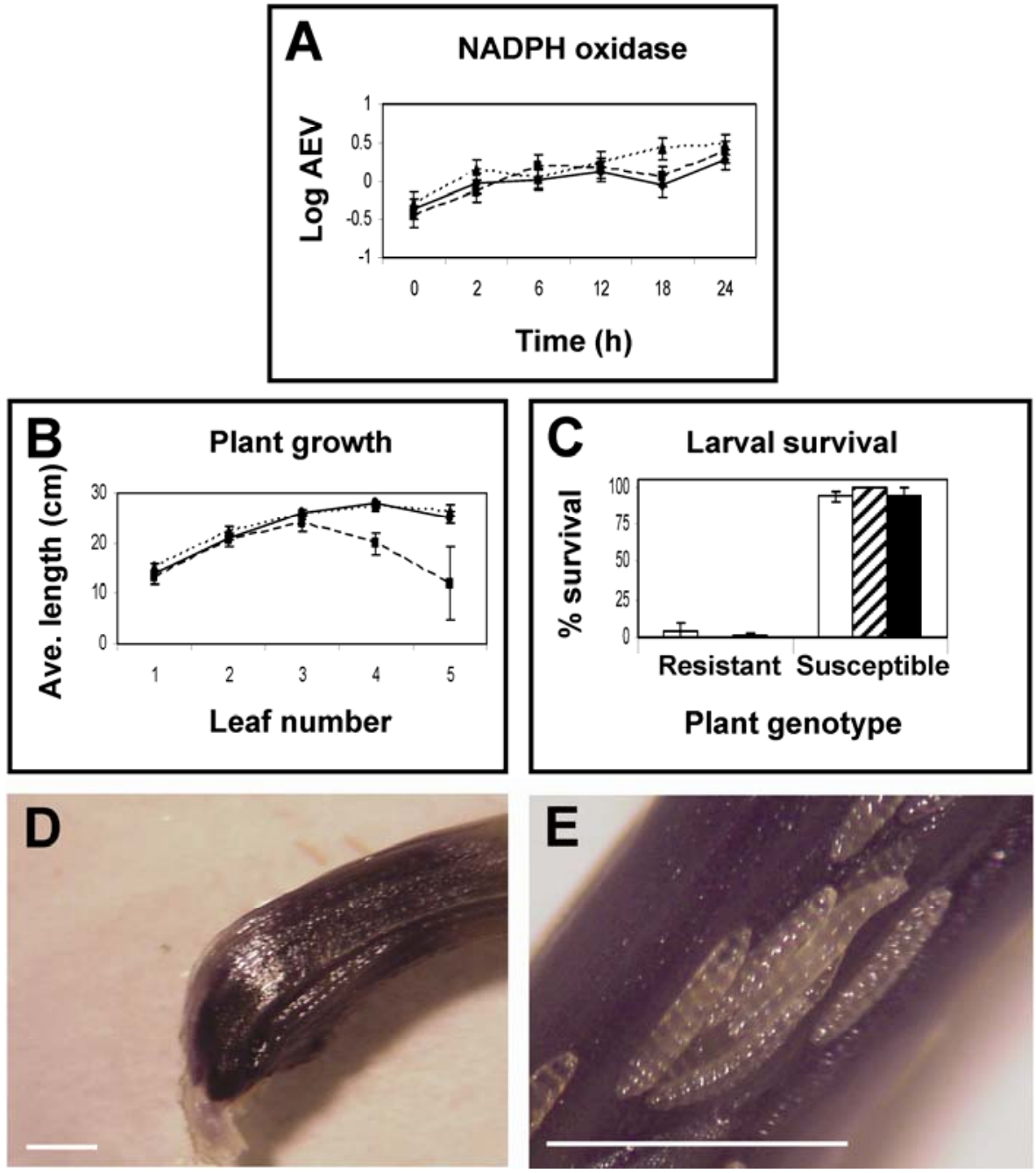

Fig. 2. Superoxide production in wheat. A, Levels of mRNA for a NOX gene involved in generation of active oxygen species. Log of the arbitrary expression values (Log $\mathrm{AEV}$ ) is shown for uninfested Iris- $H 9$ plants (solid line), $v H 9$-infested Iris- $H 9$ plants (compatible interaction, dashed line), and Biotype Linfested Iris- $\mathrm{H} 9$ plants (incompatible interaction, dotted line). Error bars represent standard error from the analysis of variance test. Tissue was harvested for total RNA isolation 1 day before hatch (0 time point) and at 2, 6, 12, 18, and $24 \mathrm{~h}$ after egg hatch. The graph represents two independent experiments, each subjected twice to quantitative real-time polymerase chain reaction. B, Average length of the first through the fifth leaves, 17 days after egg hatch, from uninfested Iris- $H 9$ wheat plants (solid line), $v H 9$-infested Iris- $H 9$ plants (compatible, dashed line), and Biotype L-infested Iris- $H 9$ plants (incompatible, dotted line). C, Average percentage of larvae surviving per plant on nearly isogenic resistant (97211) and susceptible (Len) wheat plants in the diphenyleneiodium (DPI) experiment designed to inhibit the superoxide-producing NADPH complex. Error bars represent standard error of the means. White bars represent the percentage of larvae surviving on DPI-treated resistant and susceptible plants grown in hydroponic solution. Striped bars represent the percentage of larvae surviving on resistant and susceptible plants grown in hydroponic solution without DPI. Black bars represent percentage of larvae surviving on resistant and susceptible plants grown in vermiculite without DPI. Nitro blue tetrazolium staining showed superoxide production in all tissues at the crown of $\mathbf{D}$, uninfested wheat seedlings as well as E, susceptible 'Len' wheat seedlings $12 \mathrm{~h}$ after hatch of virulent Biotype L larvae (compatible interaction). Bars represent 1 mm.

Fig. 3. Presence of hydrogen peroxide in wheat crown tissues. A through $\mathbf{C}$, mRNA levels of wheat genes involved in cellular protection from active oxygen species. Log of the arbitrary expression values (Log AEV) is shown for uninfested Iris- $H 9$ plants (solid line), $v H 9$-infested Iris- $H 9$ plants (compatible interaction, dashed line), and Biotype L-infested Iris- $\mathrm{H} 9$ plants (incompatible interaction, dotted line). Error bars represent standard error from the analysis of variance test. Tissue was harvested for total RNA isolation 1 day before hatch ( 0 time point) and at 2, 6, 12, 18, and $24 \mathrm{~h}$ after egg hatch. Each graph represents two independent experiments, each subjected twice to quantitative real-time polymerase chain reaction. mRNA profiles for A, SOD, B, CAT, and C, GST. D through $\mathbf{H}$, Iris- $H 9$ wheat crowns were stained with 3,3-diaminobenzidine during the first $96 \mathrm{~h}$ of interaction with virulent and avirulent firstinstar Hessian fly larvae. Bars represent $1 \mathrm{~mm}$. D, Incompatible interaction, $12 \mathrm{~h}$ after hatch of Biotype L Hessian fly larvae. E, Incompatible interaction, 24 $\mathrm{h}$ after hatch of Biotype L Hessian fly larvae. F, Incompatible interaction, 4 days after hatch of Biotype L Hessian fly larvae. G, Compatible interaction, $12 \mathrm{~h}$ after hatch of $v H 9$ Hessian fly larvae. $\mathbf{H}$, Iris- $H 9$ wheat infected with powdery mildew (Blumeria graminis f. sp. tritici) to show the typical brown precipitate from accumulation of $\mathrm{H}_{2} \mathrm{O}_{2}$ (compatible interaction). I, $\mathrm{H}_{2} \mathrm{O}_{2}$-dependent $2^{\prime}$, 7'-dichlorofluorescein fluorescence of leaf-three crown tissue $24 \mathrm{~h}$ after egg hatch. Photos of Iris- $H 9$ with $v H 9$ (compatible) and Iris- $H 9$ with Biotype L (incompatible) crown tissue were taken in the elongation zone where larvae feed, $1 \mathrm{~cm}$ above the root/crown junction. Photos were taken distal to the elongation zone for the negative control (uninfested Iris- $\mathrm{H} 9$ ), $3 \mathrm{~cm}$ above the root/crown junction. Bars represent $0.1 \mathrm{~mm}$. 
toxic effect. Although DPI did not increase survival of Hessian fly larvae, it did cause some yellowing of wheat plants and a noticeable decrease in root mass. Both are symptoms characteristic of plants exhibiting DPI inhibition of the NOX complexes (Foreman et al. 2003).
Detection of superoxide radicals.

Resistant, susceptible, and uninfested control plants were stained with nitro blue tetrazolium (NBT) to detect the presence of $\mathrm{O}_{2}^{-}$that may have been produced by mechanisms other than those involving NOX. The wheat lines used for these
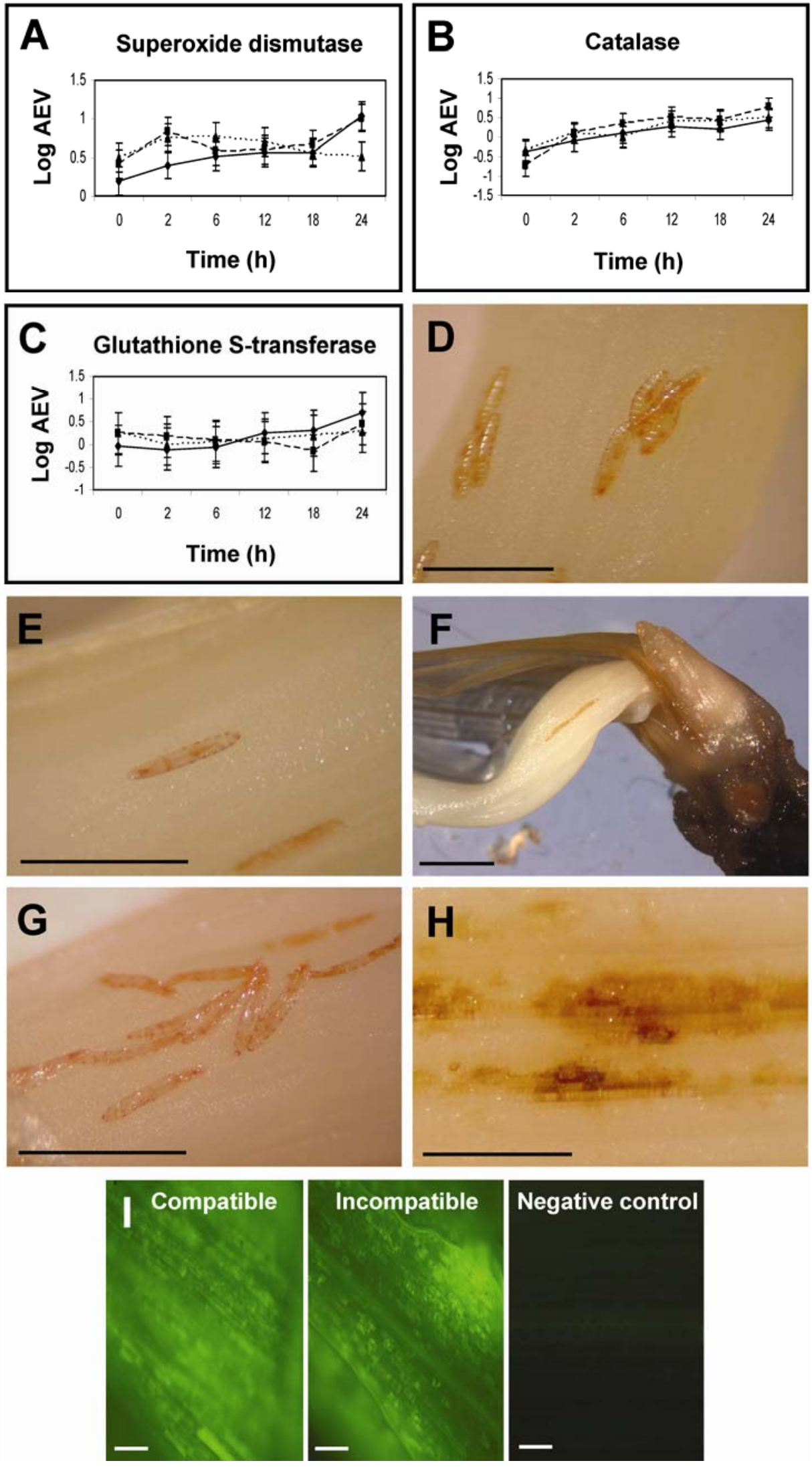
studies were nearly isogenic for resistance (line 97211) and susceptibility (line Len) to Hessian fly Biotype L. Reduction of NBT to formazan yields a bluish precipitate in the presence of $\mathrm{O}_{2}^{-}$(Doke 1983). A bluish color was observed throughout the crown tissue with an equal intensity regardless of whether the plants were uninfested controls (Fig. 2D) or involved in compatible (Fig. 2E) or incompatible (not shown) interactions. The extensive staining at the crown of the uninfested control plants indicated that $\mathrm{O}_{2}^{-}$is produced during normal cell division and growth in wheat seedlings, as was reported earlier (Selote et al. 2004). Thus, no correlations could be made between accumulation of $\mathrm{O}_{2}^{-}$and plant resistance. However, this basal level of $\mathrm{O}_{2}^{-}$could be a source of oxidative stress to both virulent and avirulent Hessian fly larvae.

\section{Accumulation of wheat $S O D, C A T$, and GST mRNA.}

The mRNA levels of wheat genes encoding antioxidative enzymes that minimize the effects of oxidative stress on the plant (SOD, CAT, and GST) (Hammond-Kosack and Jones 1996) were analyzed during the first $24 \mathrm{~h}$ of compatible (Iris- $H 9$ wheat with $v H 9$ larvae) or incompatible (Iris- $H 9$ wheat with Biotype L larvae) interactions. Comparisons of plants involved in compatible and incompatible interactions with uninfested control plants showed no differential accumulation of mRNA (Fig. 3A to C). Specific q-RT-PCR primers for all genes (Table 1) were designed from available wheat sequences.

Profiles for $S O D, C A T$, and GST mRNA resembled those described earlier for the AOS-producing NOX gene, which were derived from the same tissue samples (Figs. 2A and 3A to C). These RNAs did not increase following Hessian fly attack (all $P$ values $>0.05$ ), further supporting the earlier experiments indicating that neither oxidative burst nor AOS scavenging are induced in wheat defense against this insect pest.

\section{Assay for presence of $\mathrm{H}_{2} \mathrm{O}_{2}$ in wheat seedlings.}

Although we were unable to detect increased mRNA levels for one gene that generates and three that scavenge plant AOS, genes other than those that we evaluated may be involved in AOS production. Thus, we used histochemical staining methods to determine whether AOS in the form of $\mathrm{H}_{2} \mathrm{O}_{2}$ could be detected in crown tissues of wheat plants involved in compatible (Iris- $H 9$ with $v H 9$ larvae) or incompatible (Iris- $H 9$ with Biotype L larvae) interactions. Oxidation of 3,3-diaminobenzidine (DAB) stains tissues brown in the presence of $\mathrm{H}_{2} \mathrm{O}_{2}$ (Orozco-Cárdenas and Ryan 1999; Thordal-Christensen et al.

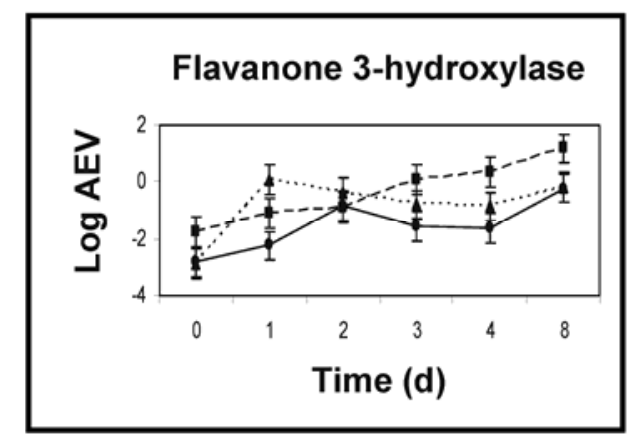

Fig. 4. Accumulation of a wheat flavanone 3-hydroxylase mRNA. Log of the arbitrary expression values (Log AEV) is shown for uninfested Iris- $H 9$ plants (solid line), $v H 9$-infested Iris- $H 9$ plants (compatible interaction, dashed line), and Biotype L-infested Iris- $H 9$ plants (incompatible interaction, dotted line). Error bars represent standard error from the analysis of variance test. Tissue was harvested for total RNA isolation 1 day before hatch ( 0 time point) and 1,2,3,4, and 8 days after egg hatch. The graph represents two independent experiments, each subjected twice to quantitative real-time polymerase chain reaction.
1997). No Hessian fly-induced increase in $\mathrm{H}_{2} \mathrm{O}_{2}$ was detected in wheat tissues with DAB after the initiation of larval feeding $(0,2,6,12,18,24,48,72$, or $96 \mathrm{~h})$ in either compatible or incompatible interactions (Fig. 3D to G). In contrast, a typical brown color originating from precipitated DAB was observed clearly in leaves of Iris- $H 9$ wheat infected with a virulent race of powdery mildew, Blumeria graminis f. sp. tritici, included as a positive control for staining (Fig. $3 \mathrm{H}$ ).

Additional controls (not shown) demonstrated that, when exogenous $\mathrm{H}_{2} \mathrm{O}_{2}$ (final concentration of $1.5 \% \mathrm{vol} / \mathrm{vol}$ ) was added to $\mathrm{DAB}$, uninfested intact wheat crown tissue and tissue homogenate stained an intense brown color, whereas DAB with added $\mathrm{H}_{2} \mathrm{O}_{2}$ but lacking wheat tissue turned light brown. These controls indicate that peroxidase was present in the tissues but $\mathrm{H}_{2} \mathrm{O}_{2}$ levels were undetectable until exogenous $\mathrm{H}_{2} \mathrm{O}_{2}$ was added. Thus, oxidative burst-associated $\mathrm{H}_{2} \mathrm{O}_{2}$ is not present in wheat crown tissue under Hessian fly attack. Finally, the cut ends of leaves stained dark brown due to production of $\mathrm{H}_{2} \mathrm{O}_{2}$ during wounding (Fig. 3F, lower right corner). Low constitutive levels of $\mathrm{H}_{2} \mathrm{O}_{2}$ were detected at the crown of both infested and uninfested plants by the more sensitive 2',7'-dichlorofluorescin (DCFH) method (Fig. 3I). This $\mathrm{H}_{2} \mathrm{O}_{2}$ was associated with the zone of cell elongation rather than with resistance.

\section{Accumulation of a wheat $\mathrm{F3H}$ mRNA.}

The previous experiments failed to associate increases in Hessian fly SOD and CAT mRNA during infestation with an endogenous oxidative burst in crown tissues in resistance mechanisms. Consequently, a mechanism capable of producing AOS inside the insect rather than within plant tissues was sought. Wheat $F 3 H$ mRNA levels were quantified because $\mathrm{F} 3 \mathrm{H}$ is a member of a gene family involved in biosynthesis of myriad pro-oxidant compounds. Some of these compounds function as insect feeding deterrents (Estiarte et al. 1999) and are capable of generating AOS upon ingestion by insects (Ahmad and Pardini 1990).

Specific q-RT-PCR primers for $F 3 H$ (Table 1) were designed from cDNA sequence obtained from a GeneCalling experiment (C. E. Williams, unpublished data). During incompatible interactions (Iris- $H 9$ plants with Biotype L larvae), $F 3 H$ mRNA was most abundant 1 day after egg hatch (Fig. 4, dotted line, 10.52fold above control, $P=0.004$ ). During compatible interactions (Iris- $H 9$ plants with $v H 9$ larvae), the levels of wheat $F 3 H$ mRNA gradually increased through the end of the experiment, 8 days after egg hatch (Fig. 4, dashed line). The most significant difference in $F 3 H$ mRNA levels between the control and compatible interaction were seen 3 and 4 days after hatch (5.2-fold, $P=0.031$ at day 3 and 7.35 -fold, $P=0.011$ at day 4$)$.

\section{DISCUSSION}

The experiments reported here were initiated as part of a program to determine the involvement of standard plant defense mechanisms in the resistance of wheat plants against firstinstar Hessian fly larvae. Our previous work demonstrated that, during incompatible interactions, a few unusual lectinlike wheat genes may be involved in the production of feeding deterrents or products that block absorption of nutrients within the larval midgut (Subramanyam et al. 2006; Williams et al. 2002) (Giovanini et al., submitted for publication). In addition, some of the most Hessian fly-responsive wheat genes also react to applications of the defense-signaling molecule, salicylic acid (Sardesai et al. 2005; Subramanyam et al. 2006). However, larvae fail to elicit a robust response from several standard wheat-defense and wound-response genes (Sardesai et al. 2005, and N. Sardesai, S. Subramanyam, and C. E. Williams, 
unpublished data). Because wheat resistance to Hessian fly is triggered by a gene-for-gene recognition (Hatchett and Gallun 1970) and a related HR-like cell death was reported earlier (Grover 1995), we investigated the involvement of an oxidative burst due to its association with these components of resistance during plant interactions with microbial pathogens.

In three independent experiments with Biotype L larvae on resistant and susceptible nearly isogenic lines of wheat, the levels and rates of increase for larval SOD and CAT RNAs differed between compatible and incompatible interactions. These results suggested that both interactions imposed stresses on larvae. However, the larval mRNA responses associated with the presence of the wheat $H 9$ resistance gene during the incompatible interaction represent profiles of larvae that may be consuming very little while in the process of dying. In contrast, the high levels of $S O D$ and gradually increasing levels of $C A T$ mRNA during the compatible interaction represent profiles of healthy Hessian fly larvae effectively dealing with the basal defenses of susceptible plants while consuming nutrients and growing.

The response of $T . n i$ to $\mathrm{O}_{2}^{-}$-generating dietary pro-oxidants is similar to that of healthy Hessian fly larvae during compatible interactions with wheat. $T$. ni SOD activity rapidly increases only twofold whereas CAT activity stays relatively constant (Ahmad and Pardini 1990). This T. $n i$ response is efficient because SOD activity catalyzes dismutation of $\mathrm{O}_{2}^{-}$radicals $10^{10}$ fold faster than the spontaneous dismutation that would occur in the absence of the enzyme (Fridovich 1983), and the constitutive level of CAT is sufficient to deal with large and rapid increases in $\mathrm{H}_{2} \mathrm{O}_{2}$ (Ahmad and Pardini 1990).

Under normal growth conditions, both $\mathrm{O}_{2}^{-}$radicals and $\mathrm{H}_{2} \mathrm{O}_{2}$ are generated at the crown of wheat seedlings where cell elongation is occurring. Because Hessian fly larvae feed in this region of the plant, they were exposed to AOS. Superoxide radicals are produced during mitochondrial electron transport (Lamb and Dixon 1997) and were found in healthy wheat seedlings at a concentration of $0.75 \mathrm{mM} / \mathrm{g}$ of dry weight (Selote et al. 2004). $\mathrm{H}_{2} \mathrm{O}_{2}$ is present at a low concentration of approximately $0.02 \mu \mathrm{M} / \mathrm{g}$ of protein in healthy wheat plants (Agarwal et al. 2005). Using $\mathrm{NBT}$ and DCFH, $\mathrm{O}_{2}^{-}$and $\mathrm{H}_{2} \mathrm{O}_{2}$ staining was indistinguishable in intensity and distribution among crowns of uninfested plants, as well as infested plants involved in compatible and incompatible interactions.

Although AOS were produced at the crown of both healthy and infested wheat plants, a classical oxidative burst appeared to play no role in resistance against the Hessian fly. DAB staining detected no difference in $\mathrm{H} 2 \mathrm{O} 2$ accumulation during the first 4 days of compatible and incompatible interactions. Wheat mRNAs encoding enzymes involved in either AOS generation (NOX) or detoxification (SOD, CAT, and GST) did not vary in abundance during the first 8 days. Furthermore, DPI inhibition of preexisting NOX complexes did not increase the survival of larvae during incompatible interactions.

In examples where an oxidative burst has been well documented, specific characteristics are evident. An extended oxidative burst is detectable within $3 \mathrm{~h}$ of initial contact during incompatible interactions between soybean cells and avirulent Pseudomonas syringae pv. glycinea (Orlandi et al. 1992). The initiation of the oxidative burst is correlated with activation of NOX catalytic subunits associated with microsomal plasma membrane fractions in Phytophthora infestans-infected potato tuber slices (Doke and Miura 1995). Once initiated, an oxidative burst may be sustained by pathogen-induced changes in RNAs encoding oxidant-generating enzymes (Lamb and Dixon 1997). Evidence of an oxidative burst in plant defense against insects is suggested in experiments where mRNA from the tomato gp91 ${ }^{\text {phox }}$ homolog (similar to the human gene encoding the heme-binding subunit of the superoxide-generating NOX complex) accumulates both locally and systemically in response to whiteflies (Walling 2000). However, none of these components of an oxidative burst were detected in our experiments.

An alternative mechanism for generating oxidative stress in Hessian fly larvae without induction of AOS production within wheat tissues may be involved in resistance. Plants produce a variety of phenolic compounds, such as quinones and flavonoids, some of which are activated to produce AOS once ingested by insects (Ahmad and Pardini 1990). The most abundant flavonoid in healthy wheat is isoorientin (Estiarte et al. 1999), a compound also found in corn silks that is extremely effective in inhibiting growth of corn earworm larvae (Widstrom and Snook 1998). A flavonoid profile has not yet been generated for wheat during interactions with Hessian fly larvae. Consequently, we can only speculate that increased production of ingestion-activated AOS-generating flavonoids plays a role in defense. However, the rapid 10.52 -fold $(P=0.004)$ increase in wheat $F 3 H$ mRNA within 24 h of attack by avirulent larvae (compatible) suggests that flavonoids may contribute to defense. In contrast, the slow increase in $F 3 H$ mRNA during compatible interactions may lead to production of compounds at a rate that allows the virulent larvae to adapt through the gradual increases in larval SOD and CAT mRNA and their encoded detoxifying enzymes.

The lack of an oxidative burst within wheat tissues suggested that the Hessian fly-induced cell death reported by Grover (1995) is due to other causes. True HR induced by another gall midge (Dasineura marginemtorquens Bremi) on resistant willow (Salix viminalis L.) spread across six cell layers within 12 $\mathrm{h}$ and led to insect death at $40 \mathrm{~h}$ after egg hatch (Ollerstam et al. 2002). However, the reaction described by Grover does not fit the criteria for an HR, because the cell collapse was evident 2 days after egg hatch in both incompatible and compatible interactions, and death of avirulent larvae occurred several days later. No morphological characteristics distinguish HR from other causes of cell death (Heath 1998). HR typically induces systemic changes throughout the plant, including induced resistance to a variety of pathogens (Kombrink and Somssich 1995). In contrast, the resistance mechanisms of wheat against avirulent Hessian fly larvae appear to be highly localized around the attempted feeding sites; thus, nearby virulent larvae are able to survive and initiate systemic changes in the plant leading to survival of both virulent and genetically avirulent larvae (Grover et al. 1989). Further work is underway to identify genes and mechanisms involved in the resistance and susceptibility mechanisms in the Hessian fly-wheat interactions.

\section{MATERIALS AND METHODS}

\section{Plant growth and Hessian fly infestations.}

Purified Hessian fly stocks were kept in a $4^{\circ} \mathrm{C}$ cold room and maintained by the United States Department of Agriculture-Agricultural Research Service (USDA-ARS) Crop Production and Pest Control Research Unit in West Lafayette, IN. Hessian fly Biotype L is virulent to wheat lines carrying resistance genes $H 3, H 5, H 6$, and $H 7 / 8$, which were used to verify fly genotype in these studies, and to wheat lines Len and Newton, which carry no resistance gene. Biotype $\mathrm{L}$ is avirulent to both line 97211 (Ratcliffe et al. 2002), which is nearly isogenic to Len, and to the Iris-H9 line of wheat (Patterson et al. 1994), which is nearly isogenic to Newton. The $v H 9$ Hessian fly stock is virulent to Iris- $H 9$.

Wheat seeds were sown, 10 to 12 per $10-\mathrm{cm}$ pot, in vermiculite with time-release fertilizer. Pots were kept at $4^{\circ} \mathrm{C}$ for a week to synchronize germination and then transferred to a growth chamber at $18^{\circ} \mathrm{C}$ with a $24-\mathrm{h}$ photoperiod so as to not induce 
temperature-sensitive or light-sensitive genes. When plants reached the one-leaf stage, they were covered with a plastic cup and infested with six to eight females and three to four males per pot. After $6 \mathrm{~h}$, adult flies were brushed off the plants. Time zero was estimated by closely monitoring egg hatch and dissecting plants periodically to determine when larvae had reached the crown of the plant and were attempting to feed. Infestations of the wheat differential lines carrying resistance genes $H 3, H 5$, $H 6$, and $H 7 / H 8$ plus the Iris- $H 9$ line were included as controls in each experiment to verify the genotype of flies; for example, experimental plant tissue for use in q-RT-PCR was destructively harvested days before symptoms of plant susceptibility or resistance could be evaluated, but the survival of Biotype L larvae on the $H 3, H 5, H 6$, and $H 7 / H 8$ control plants and their death on Iris- $H 9$ confirmed that the previously harvested experimental plant tissue had been treated correctly with the larval genotype that would trigger the desired molecular response. The phenotype of each infested differential control plant (stunted or unstunted) was evaluated 11 days after egg hatch. In addition, a subset of the experimental plants from each infested treatment (compatible and incompatible) was dissected 5 days after egg hatch, and numbers of live and dead larvae were recorded to determine infestation levels and to verify whether the expected interaction (compatible or incompatible) had occurred. Eighteen days after egg hatch, 10 plants from each treatment were measured from soil level to each ligule and to each leaf blade tip to verify stunting of susceptible plants.

\section{NBT staining for superoxides.}

Crown tissue was harvested from resistant line (97211), susceptible line (Len), and uninfested control plants from both lines at 2, 6, 12, 18, and $24 \mathrm{~h}$ after egg hatch (Biotype L) and immediately immersed in stain consisting of $0.2 \%(\mathrm{wt} / \mathrm{vol})$ NBT powder (Sigma-Aldrich, St. Louis) in deionized $\mathrm{H}_{2} \mathrm{O}$ (the experiment was done twice, each time with 5 to 10 plants per time point for each treatment). The crown tissues in stain were vacuum infiltrated and held for 5 to $6 \mathrm{~h}$ at room temperature, protected from light. The NBT solution was removed from the vials and stained tissues were fixed by vacuum infiltration with $2 \%$ formaldehyde and $2 \%$ glutaraldehyde in $50 \mathrm{mM}$ PIPES, $\mathrm{pH} 7.2$, and held overnight at $4^{\circ} \mathrm{C}$. The next day, tissues were rinsed two times for $15 \mathrm{~min}$ in $50 \mathrm{mM}$ PIPES, then washed in 95\% EtOH until tissue appeared clear. Stained tissues were stored in $70 \% \mathrm{EtOH}$. Samples were examined under a dissecting microscope (Model EMZ-TR, Sony Meiji, Tokyo) and photographed with a digital camera (Model MVC-FD88, Sony Digital Mavica, Tokyo).

\section{DPI treatment to block NADPH oxidase activity and superoxide production.}

Plants used in this experiment were from two nearly isogenic wheat lines differing in their reactions to Hessian fly biotype L; line 97211 was resistant and Len was susceptible. Plants were germinated under greenhouse conditions. After the first leaf emerged, six 97211 plants and six Len plants were placed in each of two plastic trays covered with aluminum foil to control algal growth, with roots floating in Hoagland's solution (Hoagland and Arnon 1950) under constant aeration. The trays were placed in an $18^{\circ} \mathrm{C}$ growth chamber with a 24 -h photoperiod. One day after the plants were transferred to Hoagland's solution, each tray was infested with 20 to 30 female and 15 male adult Biotype L Hessian flies under a cheesecloth tent. One day after infestation, the Hoagland's solution was changed and one tray was supplemented with $3 \mu \mathrm{M}$ DPI (Sigma-Aldrich) and the other tray was left with Hoagland's solution as a control for the DPI treatment. As controls for the hydroponic treatments, 12 plants from each of the two nearly isogenic lines were grown in vermiculite without DPI and infested as described above. Larval survival was determined by dissecting plants under a microscope and counting the living and dead larvae 5 days after eggs hatched. Living larvae were distinguished from dead red larvae by their whitish appearance and larger size. Of the six experimental Len plants grown in DPI, one plant died and another plant appeared chlorotic, possibly due to the toxicity of DPI to the plants.

\section{DAB assay for hydrogen peroxide accumulation.}

The DAB uptake method was used to detect peroxide accumulation (Thordal-Christensen et al. 1997). DAB powder (Sigma-Aldrich) was dissolved in water $(1 \mathrm{mg} / \mathrm{ml})$ by adding $\mathrm{HCl}$ to reach a $\mathrm{pH}$ of 3.8. Harvested crown tissue (five plants per time point per treatment, experiment done twice) was immersed immediately in DAB solution, vacuum infiltrated for $45 \mathrm{~s}$, and held for $8 \mathrm{~h}$ under light at $25^{\circ} \mathrm{C}$. The reaction was terminated by immersion of tissue in boiling $96 \% \mathrm{EtOH}$ for 10 min and cleared with $70 \%$ EtOH. Crown tissues were preserved in $70 \% \mathrm{EtOH}$ for photography. Uninfested, stained tissues were used as a negative control. Leaves infected with B. graminis f. sp. tritici were used as a positive control for the presence of $\mathrm{H}_{2} \mathrm{O}_{2}$. Infection of wheat leaves with $B$. graminis f. sp. tritici occurred naturally in the greenhouse due to high temperatures and humidity.

Additional controls were performed (five plants per treatment) to demonstrate that the addition of exogenous $\mathrm{H}_{2} \mathrm{O}_{2}$ turned the DAB solution brown and that peroxidase activity was present in wheat crown tissue. The controls included $1 \mathrm{ml}$ of DAB solution mixed with $1 \mathrm{ml}$ of $3 \% \mathrm{H}_{2} \mathrm{O}_{2}$ solution in the absence of wheat crown tissue, DAB plus $\mathrm{H}_{2} \mathrm{O}_{2}$ with intact or homogenized wheat crown tissue, and DAB minus $\mathrm{H}_{2} \mathrm{O}_{2}$ with intact or homogenized wheat crown tissue.

\section{DCFH assay for hydrogen peroxide accumulation.}

In the presence of hydrogen peroxide, $\mathrm{DCFH}$ is oxidized to the highly fluorescent $2^{\prime}, 7^{\prime}$-dichlorofluorescein (DCF) (Allan and Fluhr 1997; Schopfer et al. 2001; Simontacchi et al. 1993). The technique described by Rodríguez and associates (2002) and Schopfer and associates (2001) was followed with some modifications. Iris- $H 9$ plants were infested at the two-leaf stage with $v H 9$ (compatible interaction) or Biotype L (incompatible interaction) Hessian flies. One day after eggs hatched, uninfested control and infested plants were dissected to expose the entire third leaf, where larvae were feeding. The tissue was excised $1.5 \mathrm{~cm}$ below and $3.5 \mathrm{~cm}$ above the root/crown junction to avoid wound-induced fluorescence at the elongation and larval feeding zone (tissue from the root/crown junction to $2 \mathrm{~cm}$ above). Crown tissue was placed on a microscope slide and covered with $500 \mu \mathrm{l}$ of partially cooled agar solution followed by a cover slip. The following solution was heated to solubilize the agar: $1 \%$ (wt/vol) Bacto agar (Difco Laboratories, Detroit) in $20 \mathrm{mM}$ potassium phosphate buffer, $\mathrm{pH}$ 6.0, with $50 \mu \mathrm{M} 2^{\prime}, 7^{\prime}$-dichlorofluorescin diacetate (Sigma-Aldrich). For negative fluorescence controls, leaf-three blade tissue (fully expanded area) and tissue $3 \mathrm{~cm}$ above the root/crown junction (distal to the elongation zone) were collected and treated. For a positive fluorescence control, leaf tissue was covered with $1.5 \%$ ( vol $/ \mathrm{vol}$ ) $\mathrm{H}_{2} \mathrm{O}_{2}$ before adding the agar. Thirty minutes after placing the cover slip, fluorescence was viewed on a Nikon E800 microscope with excitation and emission wavelengths of $470 \pm 20$ and $525 \pm 25 \mathrm{~nm}$, respectively. Images were captured with a SPOT RT Slider digital camera.

\section{Cloning of the wheat NADPH oxidase partial cDNA.}

We cloned a 794-bp cDNA fragment from the NOX gene by PCR, using a pair of primers (forward: 5'-TAT ATG TTT GTT 
CAA TGT CC-3' and reverse: 5'-GCT CCA CAG TAG AAT ACA CC-3') designed from Rice EST accession: X93301 (Amicucci et al. 1999). The template for PCR cloning was cDNA synthesized from total RNA from crown tissue of an $F_{1}$ hybrid (97211/Len) $72 \mathrm{~h}$ after hatch of Biotype L larvae. The PCR contained $1 \mathrm{ml}$ of template cDNA $(0.1 \mathrm{mg}), 0.2 \mu \mathrm{M}$ each primer, $200 \mu \mathrm{M}$ dNTPs, $50 \mathrm{mM} \mathrm{KCl}, 2 \mathrm{mM} \mathrm{MgCl} 2,10 \mathrm{mM}$ Tris- $\mathrm{HCl}, \mathrm{pH} 8.3,0.001 \%$ gelatin, and $1 \mathrm{U}$ of Taq DNA polymerase in a final volume of $50 \mathrm{ml}$. PCR was initiated with denaturation at $94^{\circ} \mathrm{C}$ for $2 \mathrm{~min}$, followed by 32 cycles of $94^{\circ} \mathrm{C}$ for $15 \mathrm{~s}$ of denaturation, $43^{\circ} \mathrm{C}$ for $30 \mathrm{~s}$ of annealing, and $72^{\circ} \mathrm{C}$ for 2 min of extension, followed by a final extension at $72^{\circ} \mathrm{C}$ for $10 \mathrm{~min}$. PCR products were subjected to electrophoresis on a $0.8 \%$ agarose gel and DNA was visualized by ethidium bromide staining. The resulting amplicon was excised from the gel and purified using the Wizard plus SV minipreps DNA purification kit (Promega Corp., Madison, WI, U.S.A.). The purified fragment was cloned into the pCR 4-TOPO vector using the TOPO TA cloning kit (Invitrogen, Carlsbad, CA, U.S.A.). DNA was isolated from transformed colonies using the Wizard Plus SV minipreps DNA purification kit (Promega Corp.). The sequence of this wheat fragment (GenBank accession AY561153) shared a high degree of identity ( $e$ value $=1 \mathrm{e}-146$ ) with the rice $N O X$ gene $R b o h A$. Consequently, this wheat sequence was used in the design of q-RT-PCR primers for the $N O X$ gene of wheat (Table 1).

\section{Cloning of the Hessian fly $S O D$ and $C A T$ partial cDNAs.}

A 442-bp cDNA fragment from the Hessian fly $S O D$ gene and a 507-bp fragment from the CAT gene were recovered from a larval midgut cDNA library (Mittapalli et al. 2005). The Hessian fly SOD-deduced amino acid sequence (GenBank accession DV752666) shared 76\% identity $(e$ value $=1 \mathrm{e}-59)$ with the Musca domestica (Linnaeus) SOD, and the CAT-deduced amino acid sequence (GenBank accession DV752667) shared $71 \%$ identity $(e$ value $=1 \mathrm{e}-105)$ with Bombyx mori (Linnaeus) CAT.

\section{RNA extraction.}

Plant tissue containing larvae was harvested and stored at $-80^{\circ} \mathrm{C}$ until it was homogenized to a fine powder in liquid nitrogen. In a mortar, $2.7 \mathrm{ml}$ of TRIzol reagent (Invitrogen) was added to approximately $400 \mathrm{mg}$ of ground crown tissue (pooled from 10 to 15 plants). The extraction procedure followed the protocol described by Puthoff and associates (2005).

Total RNA was extracted from whole larvae, using the RNAqueous-4PCR kit (Ambion, Austin, TX, U.S.A.) following the manufacturer's protocol and Mittapalli and associates (2005).

\section{q-RT-PCR.}

Primers were designed from wheat plant and Hessian fly gene sequences (Table 1, sequence accession numbers) using the Primer Express software from Applied Biosystems (Foster City, CA, U.S.A.). Quantification of RNA for q-RT-PCR was conducted according to Spangler and associates (2003) and Puthoff and associates (2003) with modifications. In brief, $4.35 \mu \mathrm{g}$ of total RNA in $10 \mu \mathrm{l}$ of water was treated with DNase using the DNA-free kit (Ambion) following the manufacturer's instructions. The reverse transcriptase reaction to generate the cDNA for use in q-RT-PCR was carried out using the SuperScript First Strand cDNA Synthesis kit (Invitrogen) as follows: $1 \mu \mathrm{l}$ of oligo d(T) primer and $1 \mu \mathrm{l}$ of dNTPs were added to the $10 \mu \mathrm{l}$ of total RNA. The mixture was heated at $65^{\circ} \mathrm{C}$ for $5 \mathrm{~min}$ and then placed on ice. The following were added on ice: $2 \mu \mathrm{l}$ of $10 \times$ first-strand buffer, $2 \mu \mathrm{l}$ of $50 \mathrm{mM} \mathrm{MgCl} 2,2 \mu \mathrm{l}$ of $0.1 \mathrm{M}$ dithiothreitol, $1 \mu \mathrm{l}$ of RNaseOut, and $1 \mu \mathrm{l}$ of SuperScript II reverse transcriptase. In order to monitor cDNA synthesis in a parallel tracer reaction, $5 \mu$ were removed from each sample and mixed with $1 \mu \mathrm{l}$ of a 1:5 dilution of ${ }^{32} \mathrm{P}-\mathrm{dCTP}$ (Amersham, Piscataway, NJ, U.S.A.) in water. The remaining $15 \mu \mathrm{l}$ of each reverse transcriptase reaction and its $5 \mu$ l tracer reaction were incubated at $42^{\circ} \mathrm{C}$ for $2 \mathrm{~h}$. Reactions were stopped by heating samples at $70^{\circ} \mathrm{C}$ for $15 \mathrm{~min}$. After cDNA synthesis was stopped, the $15-\mu l$ reverse transcriptase reactions were placed on ice while the ${ }^{32} \mathrm{P}$-tracer reactions were used to quantify the amount of cDNA synthesized. From each ${ }^{32} \mathrm{P}$-tracer reaction, 5 $\mu \mathrm{l}$ was spotted onto a DE-81 filter (Fisher, Fairlawn, NJ, U.S.A.). Filters were dried for $10 \mathrm{~min}$, then washed four times for $4 \mathrm{~min}$ each in $0.5 \mathrm{M}$ sodium phosphate buffer (1 M monobasic and $1 \mathrm{M}$ dibasic in 4 liters of water). Following two 1min rinses in water, filters were washed in $95 \% \mathrm{EtOH}$ and allowed to dry. Each filter was placed in a scintillation vial containing $5 \mathrm{ml}$ of ScintiVerse (Fisher) and radiation in each filter from the cDNA was quantified in a scintillation counter. The resulting counts were used to normalize the cDNA from the corresponding reverse transcriptase reactions to a final concentration of $10 \mathrm{ng} / \mu \mathrm{l}$ of sample. Correct normalization for equal concentration of cDNA among samples was confirmed by PCR amplification with ubiquitin primers (Table 1, UBQ) for normalized wheat samples and actin primers (Table 1, ACT) for normalized Hessian fly samples (data not shown).

PCR was conducted on an ABI 7000 using the following mixture: $2 \mu \mathrm{l}$ of normalized cDNA, $10 \mu \mathrm{l}$ of $2 \times$ SYBR Green Mix (ABI, Foster City, CA, U.S.A.) and $0.25 \mu \mathrm{M}$ each primer in a $20-\mu l$ reaction. Reactions were carried out using the following cycling parameters: $50^{\circ} \mathrm{C}$ for $2 \mathrm{~min}, 95^{\circ} \mathrm{C}$ for $10 \mathrm{~min}$, and 40 cycles of $95^{\circ} \mathrm{C}$ for $10 \mathrm{~s}$ and $60^{\circ} \mathrm{C}$ for $1 \mathrm{~min}$. At the end of each run, a melt curve analysis was conducted to ensure primer specificity and purity of the PCR product. Relative mRNA levels were calculated by the standard curve method (User Bulletin 2, ABI PRISM 7700 Sequence Detection System) as described here. Briefly, an aliquot was taken from each cDNA sample used in an experiment to construct a pooled sample (for example, cDNA aliquots were taken from samples for times $0,2,6,12,18$, and $24 \mathrm{~h}$ from uninfested controls as well as from plants undergoing compatible and incompatible interactions; equal aliquots were pooled from each of the 18 samples) (Fig. 2A and B). This pooled sample was serially diluted and subjected to q-RT-PCR. The threshold cycle for each dilution was plotted against its cDNA concentration (with an arbitrary starting quantity for the undiluted pooled sample assigned the value of 1), and used as the standard curve regression equation to generate the AEV for the experimental samples. A standard curve was generated for each target gene on the same PCR plate that held the time series of experimental samples. Linear standard curves, with a slope between -3.5 and -3.2 and $R^{2}$ value $>0.99$, were required for all primers used in this study. For quantification of plant mRNA levels, two independent sets of plants were grown (time series was collected twice) and each set of cDNA samples was subjected to q-RT-PCR twice for each gene that was analyzed. Replicates for larval gene quantification were handled the same way, except that the time series was collected from three independent experiments.

\section{Statistical analysis of q-RT-PCR data.}

Quantification of the mRNA levels for all genes used in this study is shown in $\log$ (base 10) scale (log AEV) so that data for treatments with high levels of mRNA can be viewed on the same graph with data for treatments showing little change. Error bars calculated from the analysis of variance (ANOVA) test were the same for all samples and time points due to the nature of the analysis. Significance of the data was determined for 
each gene by ANOVA using the PROC MIXED procedure of SAS (SAS Institute 1999). The analysis model included treatments (compatible, incompatible, and uninfested), time points, and interaction between treatments and time points as fixed effects. Data from two biological replicates, each composed of two technical replicates, were combined and included as a random effect in the analysis model. Orthogonal contrasts were used to evaluate whether the effects of treatment or treatmenttime point interaction on $\log$ value of the AEV were significant. The $P$ values from the ANOVA test are indicated in the results only for time points of interest. Two treatments were considered to have statistically different AEVs at a particular time point if the $P$ value associated with the contrast was less than 0.05. Fold changes were calculated from AEV before the data were log-transformed.

\section{ACKNOWLEDGMENTS}

This is a joint contribution by the USDA-ARS and Purdue University. Research was supported in part by USDA CRIS number 3602-22000-02000D and Ag Alumni Seeds, Romney, IN, 47981. M. P. Giovanini received a research fellowship from the Coordenação de Aperfeiçoamento de Pessoal de Nível Superior (CAPES) program at the Ministry of Education of Brazil. This publication is Purdue University agricultural experiment station journal article number 2005-17587. We thank S. Cambron, USDA-ARS, for maintaining Hessian fly stocks used in this study, C. Sadof and E. Rebek for providing the microscope and digital camera used to take photographs, and K. A. Lennon for assistance with the discussion section and staining procedures. Special thanks to G. Shaner for his valuable critical reading of the manuscript and M. Gonzalo for advice and statistical analysis of the qRT-PCR data.

\section{LITERATURE CITED}

Agarwal, S., Sairam, R. K., Srivastava, G. C., and Meena, R. C. 2005. Changes in antioxidant enzyme activity and oxidative stress by abscisic and salicylic acid in wheat genotypes. Biol. Plant. 49:541-550.

Ahmad, S., and Pardini, R. S. 1990. Mechanisms for regulating oxygen toxicity in phytophagous insects. Free Radic. Biol. Med. 8:401-413.

Allan, A. C., and Fluhr, R. 1997. Two distinct sources of elicited reactive oxygen species in tobacco epidermal cells. Plant Cell 9:1559-1572.

Amicucci, E., Gaschler, K., and Ward, J. M. 1999. NADPH oxidase genes from tomato (Lycopersicon esculentum) and curly-leaf pondweed (Potamogeton crispus). Plant Biol. 1:524-528.

Auh, C., and Murphy, T. M. 1995. Plasma membrane redox enzyme is involved in the synthesis of $\mathrm{O}_{2}^{-}$and $\mathrm{H}_{2} \mathrm{O}_{2}$ by Phytophthora elicitorstimulated rose cells. Plant Physiol. 107:1241-1247.

Berryman, A. A., and Ferrell, G. T. 1988. The fir engraver beetle in western states. Pages 555-577 in: Dynamics of Forest Insect Populations: Patterns, Causes, Implications. A. A Berryman, ed. Plenun, New York.

Bolwell, G. P., and Wojtaszek, P. 1997. Mechanisms for the generation of reactive oxygen species in plant defence-a broad perspective. Physiol. Mol. Plant Pathol. 51:347-366.

Cartwright, W. B., Caldwell, R. M., and Compton, L. E. 1959. Responses of resistant and susceptible wheats to Hessian fly attack. Agron. J. 51:529-531.

Cosgrove, D. J., Gilroy, S., Kao, T., Ma, H., and Schultz, J. C. 2000. Plant signaling 2000. Cross talk among geneticists, physiologists, and ecologists. Plant Physiol. 124:499-505.

Cross, A. R., and Jones, O. T. 1986. The effect of the inhibitor diphenyleneiodonium on the superoxide-generating system of neutrophils. Specific labeling of a component polypeptide of the oxidase. Biochem. J. 237:111-116.

Dixon, R. A., Harrison, M. J., and Lamb, C. J. 1994. Early events in the activation of plant defense responses. Annu. Rev. Phytopathol. 32:479-501.

Doke, N. 1983. Involvement of superoxide anion generation in the hypersensitive response of potato tuber tissues to infection with an incompatible race of Phytophthora infestans and to the hyphal wall components. Physiol. Mol. Plant Pathol. 23:345-357.

Doke, N. 1985. NADPH-dependent $\mathrm{O}_{2}^{-}$generation in membrane fractions isolated from wounded potato tubers inoculated with Phytophthora infestans. Physiol. Mol. Plant Pathol. 27:311-322.

Doke, N., and Miura, Y. 1995. In vitro activation of NADPH-dependent $\mathrm{O}_{2}^{-}$-generating system in a plasma membrane-rich fraction of potato tuber tissues by treatment with an elicitor from Phytophthora infestans or with digitonin. Physiol. Mol. Plant Pathol. 46:17-28.

Estiarte, M., Peñuelas, J., Kimball, B. A., Hendrix, D. L., Pinter, P. J., Jr., Wall, G. W., LaMorte, R. L., and Hunsaker, D. J. 1999. Free-air CO$_{2}$ enrichment of wheat: Leaf flavonoid concentration throughout the growth cycle. Physiol. Plant. 105:423-433.

Fernandes, G. H., and Negreiros, D. 2001. The occurrence and effectiveness of hypersensitive reaction against galling herbivores across host taxa. Ecol. Entomol. 26:46-55.

Foreman, J., Demidchik, V., Bothwell, J. H., Mylona, P., Miedema, H., Torres, M. A., Linstead, P., Costa, S., Brownlee, C., Jones, J. D., Davies, J. M., and Dolan, L. 2003. Reactive oxygen species produced by NADPH oxidase regulate plant cell growth. Nature 422:442-446.

Fridovich, I. 1983. Superoxide radical: An endogenous toxicant. Annu. Rev. Pharmacol. Toxicol. 23:239-257.

Gallun, R. L. 1977. Genetic basis of Hessian fly epidemics. Ann. N. Y. Acad. Sci. 287:223-229.

Gallun, R. L., Deay, H. O., and Cartwright, W. B. 1961. Four races of Hessian fly selected and developed from an Indiana population. Purdue Univ. Agric. Exp. Stn. Res. Bull. 732:1-8.

Giovanini, M. P., Saltzmann, K. D., Puthoff, D. P., Gonzalo, D. P., Ohm, H. W., and Williams, C. E. A novel wheat gene encoding a putative chitin-binding lectin is associated with resistance against Hessian fly. Submitted for publication.

Groom, Q. J., Torres, M. A., Fordham-Skelton, A. P., Hammond-Kosack, K. E., Robinson, N. J., and Jones, J. D. G. 1996. rbohA, a rice homologue of the mammalian $g p 91^{\text {phox }}$ respiratory burst oxidase gene. Plant J. 10:515-522.

Grover, P. B. J. 1995. Hypersensitive response of wheat to Hessian fly. Entomol. Exp. Appl. 74:283-294.

Grover, P. B. J., Shukle, R. H., and Foster, J. E. 1989. Interactions of Hessian fly (Diptera: Cecidomyiidae) biotypes on resistant wheat. Environ. Entomol. 18:687-690.

Hammond-Kosack, K. E., and Jones, J. D. G. 1996. Resistance gene-dependent plant defense responses. Plant Cell 8:1773-1791.

Harris, M. O., Stuart, J. J., Mohan, M., Nair, S., Lamb, R. J., and Rohfritsch, O. 2003. Grasses and gall midges: Plant defense and insect adaptation. Annu. Rev. Entomol. 48:549-577.

Harris, M. O., Freeman, T. P., Rohfritsch, O., Anderson, K. G., Payne, S. A., and Moore, J. A. 2006. Virulent Hessian fly (Diptera: Cecidomyiidae) larvae induce a nutritive tissue during compatible interactions with wheat. Ann. Entomol. Soc. Am. 99:305-316.

Hatchett, J. H., and Gallun, R. L. 1970. Genetics of the ability of the Hessian fly, Mayetiola destructor, to survive on wheat having different genes for resistance. Ann. Entomol. Soc. Am. 63:1400-1407.

Hatchett, J. H., Kreitner, G. L., and Elzinca, R. J. 1990. Larval mouthparts and feeding mechanism of the Hessian fly (Diptera: Cecidomyiidae). Ann. Entomol. Soc. Am. 83:1137-1147.

Heath, M. C. 1998. Apoptosis, programmed cell death and the hypersensitive response. Eur. J Plant Pathol. 104:117-124.

Hoagland, D. R., and Arnon, D. I. 1950. The water-culture method for growing plants without soil. Univ. Calif. Agric. Exp. Stn. Circ. 347:

Hodnick, W. F., Kalyanaraman, B., Pritsos, C. A., and Pardini, R. S. 1989. The production of hydroxyl and semiquinone free radicals during the autoxidation of redox active flavonoids. Pages 149-152 in: Oxygen Radicals in Biology and Medicine. M. G. Simic, K. A. Taylor, J. F. Ward, and C. von Sonntag, eds. Plenum Press, New York.

Kepler, L. D., Baker, C. J., and Atkinson, M. M. 1989. Active oxygen production during a bacteria-induced hypersensitive reaction in tobacco suspension cells. Physiol. Biochem. 79:974-978.

Kombrink, E., and Somssich, I. E. 1995. Defense responses of plants to pathogens. Pages 1-34 in: Advances in Botanical Research, Vol. 21. J. H. Andrews and I. C. Tommerup, eds. Academic Press, London.

Lamb, C., and Dixon, R. A. 1997. The oxidative burst in plant disease resistance. Annu. Rev. Plant Physiol. Plant Mol. Biol. 48:251-275.

Levine, A., Tenhaken, R., Dixon, R., and Lamb, C. 1994. $\mathrm{H}_{2} \mathrm{O}_{2}$ from the oxidative burst orchestrates the plant hypersensitive disease response. Cell 79:583-593.

Liu, X., Fellers, J. P., Wilde, G. E., Stuart, J. J., and Chen, M. 2004. Characterization of two genes expressed in the salivary glands of the Hessian fly, Mayetiola destructor (Say). Insect Biochem. Mol. Biol. 34:229-237.

Missirlis, F., Phillips, J. P., and Jäckle, H. 2001. Cooperative action of antioxidant defense systems in Drosophila. Curr. Biol. 11:1272-1277.

Mittapalli, O., Neal, J. J., and Shukle, R. H. 2005. Differential expression of two cytochrome P450 genes in compatible and incompatible Hessian fly/wheat interactions. Insect Biochem. Mol. Biol. 35:981-989.

O’Donnell, V. B., Tew, D. G., Jones, O. T. G., and England, P. J. 1993. Studies on the inhibitory mechanism of iodonium compounds with special reference to neutrophil NADPH oxidase. Biochem. J. 290:41-49.

Ollerstam, O., Rohfritsch, O., Hoglund, S., and Larsson, S. 2002. A rapid 
hypersensitive response associated with resistance in the willow Salix viminalis against the gall midge Dasineura marginemtorquens. Entomol. Exp. Appl. 102:153-162.

Orlandi, E. W., Hutcheson, S. W., and Baker, C. J. 1992. Early physiological responses associated with race-specific recognition in soybean leaf tissue and cell suspensions treated with Pseudomonas syringae pv. glycinea. Physiol. Mol. Plant Pathol. 40:173-180.

Orozco-Cárdenas, M., and Ryan, C. A. 1999. Hydrogen peroxide is generated systemically in plant leaves by wounding and systemin via the octadenoid pathway. Proc. Natl. Acad. Sci. U.S.A. 96:6553-6557.

Patterson, F. L., Maas, F. B., III, Foster, J. E., Ratcliffe, R. H., Cambron, S. E., Safranski, G., Taylor, P. L., and Ohm, H. W. 1994. Registration of eight Hessian fly resistant common winter wheat germplasm lines (Carol, Erin, Flynn, Iris, Joy, Karen, Lola, and Molly). Crop Sci. 34:315-316.

Puthoff, D. P., Nettleton, D., Rodermel, S. R., and Baum, T. J. 2003. Arabidopsis gene expression changes during cyst nematode parasitism revealed by statistical analyses of microarray expression profiles. Plant J. 33:911-921

Puthoff, D. P., Sardesai, N., Subramanyam, S., Nemacheck, J. A., and Williams, C. E. 2005. Hfr-2, a wheat cytolytic toxin-like gene, is upregulated by virulent Hessian fly larval feeding. Mol. Plant. Pathol. 6:411-423.

Ratcliffe, R. H., Patterson F. L., Cambron, S. E., and Ohm, H. W. 2002. Resistance in durum wheat sources to Hessian fly (Diptera: Cecidomyiidae) populations in Eastern USA. Crop Sci. 42:1350-1356.

Robinson, R. J., Miller, B. S., Miller, H. L., Mussman, H. C., Johnson, J. A., and Jones, E. T. 1960. Chloroplast number in leaves of normal wheat plants and those infested with Hessian fly or treated with maleic hydrazine. J. Econom. Entomol. 53:560-566.

Rodríguez, A. A., Grunberg, K. A., and Taleisnik, E. L. 2002. Reactive oxygen species in the elongation zone of maize leaves are necessary for leaf extension. Plant Physiol. 129:1627-1632.

Sardesai, N., Subramanyam, S., Nemacheck, J. A., and Willimas, C. E. 2005. Modulation of defense-response gene expression in wheat during Hessian fly larval feeding. J. Plant Interact. 1:39-50.

SAS Institute. 1999. SAS/STAT User's Guide, Version 8. SAS Institute Cary, NC, U.S.A..

Scandalios, J. G. 1993. Oxygen stress and superoxide dismutases. Plant Physiol. 101:7-12.
Schopfer, P., Plachy, C., and Frahry, G. 2001. Release of reactive oxygen intermediates (superoxide radicals, hydrogen peroxide, and hydroxyl radicals) and peroxidase in germinating radish seeds controlled by light, gibberellin, and abscisic acid. Plant Physiol. 125:1591-1602.

Selote, D. S., Bhartib, S., and Khanna-Chopra, R. 2004. Drought acclimation reduces $\mathrm{O}_{2}^{-}$accumulation and lipid peroxidation in wheat seedlings. Biochem. Biophys. Res. Commun. 314:724-729.

Shukle, R. H., Grover, P. B. J., and Mocelin, G. 1992. Responses of susceptible and resistant wheat associated with Hessian fly (Diptera: Cecidomyiidae) infestation. Environ. Entomol. 21:845-853.

Simontacchi, M., Caro, A., Fraga, C. G., and Puntarulo, S. 1993. Oxidative stress affects $\alpha$-tocopherol content in soybean embryonic axes upon imbibition and following germination. Plant Physiol. 103:949953.

Spangler, R., Goddard, N. L., Avena, N. M., Hoebel, B. G., and Leibowitz, S. F. 2003. Elevated D3 dopamine receptor mRNA in dopaminergic and dopaminoceptive regions of the rat brain in response to morphine. Mol. Brain Res. 111:74-83.

Subramanyam, S., Sardesai, N., Puthoff, D. P., Meyer, J. M., Nemacheck, J. A., Gonzalo, M., and Williams, C. E. 2006. Expression of two wheat defense-response genes, $H f r-1$ and $W c i-1$, under biotic and abiotic stresses. Plant Sci. 170:90-103.

Sutherland, M. W. 1991. The generation of oxygen radicals during host plant responses to infection. Physiol. Mol. Plant Pathol. 39:79-93.

Thordal-Christensen, H., Zhang, Z., Wei, Y., and Collinge, D. B. 1997. Subcellular localization of $\mathrm{H}_{2} \mathrm{O}_{2}$ in plants: $\mathrm{H}_{2} \mathrm{O}_{2}$ accumulation in papillae and hypersensitive response during the barley-powdery mildew interaction. Plant J. 11:1187-1194.

Walling, L. L. 2000. The myriad plant responses to herbivores. J. Plant Growth Regul. 19:195-216.

Widstrom, N. W., and Snook, M. E. 1998. A gene controlling biosynthesis of isoorientin, a compound in corn silks antibiotic to the corn earworm. Entomol. Exp. Appl. 89:119-124.

Williams, C. E., Collier, C. C., Nemacheck, J. A., Chengzhi, L., and Cambron, S. E. 2002. A lectin-like wheat gene responds systemically to attempted feeding by avirulent first-instar Hessian fly larvae. J. Chem. Ecol. 28:1411-1428.

Zhu-Salzman K., Salzman, R. A., Ahn, J., and Koiwa, H. 2004. Transcriptional regulation of sorghum defense determinants against a phloemfeeding aphid. Plant Physiol. 134:420-431. 